\title{
Sentenças declaratórias, sentenças condenatórias e eficácia executiva dos julgados
}

\author{
Teori Albino Zavascki*
}

\section{INTRODUÇÃO}

Em conhecido estudo sobre a natureza da sentença condenatória civil, o Professor Barbosa Moreira inicia suas reflexões com a seguinte afirmação: "É sabido que só a sentença condenatória atribui à parte vencedora o poder de promover ação executória contra o sucumbente. Nenhuma outra sentença é apta a produzir tal efeito. Não o produz decerto, ainda quando reconheça ao autor a titularidade de um crédito em face do réu, a sentença meramente declaratória: tornando-se exigível o crédito declarado, e não se dispondo a satisfazê-lo o devedor, cumpre ao credor voltar a ajuízo com ação condenatória, e apenas a nova sentença que lhe julgue procedente o pedido constituirá em seu favor título hábil para a execução forçada." E depois de examinar as várias correntes doutrinárias a respeito do tema e de referir que, ao fim e ao cabo, "a sentença condenatória já não se distinguiria da declaratória senão pela extensão do declarado, que nesta seria apenas o crédito (lato sensu) de uma contra a outra parte, naquela o crédito $e$ mais a sanção aplicável à parte inadimplente," ${ }^{2}$ encerra seu trabalho com uma pergunta não respondida: "Em que consiste, afinal, a declaração capaz de proporcionar à parte vencedora título hábil para a execução forçada? A resposta de Liebman, vazada em fórmula mais aderente à realidade soaria: na declaração da aplicabilidade da sanção. Ora, justamente nisso é que não se pode convir sem fazer tábua rasa das hipóteses em que o juiz condena e se executa, sem que se trate em absoluto de san-

\footnotetext{
* Ministro do STJ, Professor de Processo Civil na UFRGS.

1 MOREIRA, José Carlos Barbosa. Reflexões Críticas sobre uma Teoria da Condenação Civil. In: TEMAS de Direito Processual Civil: 1a Série. São Paulo: Saraiva, 1977. p. 72.

2 Ibidem, p. 77.
} 
ção; e também daquelas outras, não tão raras, em que a sanção se efetiva na própria sentença, sem necessidade nem, aliás, possibilidade - de repor-se em movimento, para atuá-la, o mecanismo judicial."

Bem se vê, do excerto referido, que o interesse científico e prático do estudo do tema relacionado com o conceito de sentença condenatória e o de sentença puramente declaratória, e as respectivas distinções, reside, justamente, na delimitação da eficácia de cada uma, notadamente no âmbito da sua eficácia executiva. Condenação, mera declaração e força executiva constituem, portanto, temas imbricados, e nesta perspectiva é que aqui serão versados.

\section{NATUREZA E CONTEÚDO DOS TÍTULOS EXECUTIVOS}

A eficácia executiva dos julgados pressupõe compreensão a respeito da natureza e do conteúdo do título executivo, que é a "base" de toda e qualquer execução, segundo dispõe o artigo 583 do CPC. O princípio da nulla executio sine titulo integra a dinâmica da concretização do ordenamento jurídico. Realmente, o fenômeno da atuação das normas no plano social comporta três momentos bem distintos: primeiro, o da formulação abstrata dos preceitos normativos; segundo, o da definição da norma para o caso concreto; e terceiro, o da execução da norma individualizada. A formulação abstrata dos preceitos normativos, ou seja, a criação das normas (momento 1) é ativi- dade pública monopolizada pelo Estado-legislador. Já a definição da norma concreta, é dizer, a identificação da norma individualizada que se formou, concretamente, pela incidência da norma abstrata (momento 2), bem como a sua execução, ou seja, a sua transformação efetiva em fatos ou comportamentos (momento 3), são atividades que não demandam, necessariamente, o concurso ou a intervenção estatal.

As atividades dos momentos 2 e 3 desenvolvem-se, em geral, de modo espontâneo, voluntário e sem formalidades. Assim, nas mais simples condutas do dia-a-dia, como as de comprar um jornal ou tomar um táxi, há incidência de normas abstratas em suportes fáticos, nascem normas jurídicas concretas, os seus destinatários identificam o seu conteúdo e os elementos das relações jurídicas que a partir delas são estabelecidas (sujeitos ativos, sujeitos passivos, prestações) e, finalmente, há cumprimento dos seus enunciados, mediante condutas e comportamentos com eles compatíveis.

Em certos casos, o momento 2, embora ocorra voluntariamente (isto é, sem intervenção estatal), se dá de modo formal. É assim, por exemplo, quando se ajusta contrato em forma escrita, na presença de testemunhas ou perante um tabelião, ou quando se emite um título de crédito. O que se faz, nessas situações, é formalizar documentalmente o conteúdo de determinada norma jurídica concreta, identificando os elementos da relação de direito exsurgente, o sujeito ativo, o sujeito passivo e a pres- 
tação, com o seu objeto, seu prazo e suas condições. Quando a formalização documental tiver natureza constitutiva da obrigação - que é o que geralmente ocorre nos casos acima enfocados - haverá contemporaneidade entre incidência da norma abstrata e identificação da norma concreta que daí nasce. Casos há em que a lei autoriza a identificação da norma concreta mediante procedimento administrativo. É o que se dá, por exemplo, nos procedimentos fiscais de lançamento de tributo e sua inscrição em dívida ativa. E há casos em que os interessados estão autorizados a delegar a terceiro, também particular, o encargo de identificar os contornos da norma individualizada. É o que ocorre quando determinada controvérsia é submetida a juízo arbitral. Também nessas hipóteses o momento 3 é, em regra, espontâneo: os destinatários da norma concretizada (formalizada no contrato ou no título de crédito, ou na certidão de dívida ativa ou na sentença arbitral), dão-lhe o devido cumprimento, adotando a conduta adequada à satisfação da prestação devida.

No entanto, a identificação da norma concreta ou a sua execução, ou ambas, quando não desenvolvidas voluntariamente, demandam concurso estatal, o que se dá pela atuação do Estado-juiz, mediante exercício da sua função jurisdicional. Tomemos um exemplo. O choque entre dois automóveis, com danos recíprocos, é suporte fático para a incidência da norma estabelecida no artigo 159 do Código Civil: "aquele que, por ação ou omissão voluntária, negligência, ou imprudência, violar direito ou causar prejuízo a outrem, fica obrigado a repa- rar o dano". Ocorrido o fato, a incidência do preceito normativo abstrato é automática, de modo que, independentemente da vontade dos envolvidos, surge norma jurídica concreta, estabelecendo relação obrigacional de reparação dos prejuízos. A identificação de tal norma supõe imputação da culpa, com conseqüente posicionamento dos envolvidos nos pólos ativo e passivo da relação obrigacional, e apuração dos danos e do seu montante, que é a prestação devida. Nem sempre haverá entre os interessados consenso a respeito de todos esses pontos. Nem sempre haverá, portanto, espontaneidade de identificação da norma individualizada. Estabelecendo-se controvérsia a respeito de qualquer dos aspectos assinalados, estará instalada crise de identificação da norma, a demandar, para a sua solução, intervenção estatal. Mediante atividade cognitiva, o Poder Judiciário definirá, por sentença, o conteúdo da norma concretizada, indicando os elementos da relação jurídica dela decorrente, seus sujeitos e sua prestação. Definida a norma concreta, a atividade jurisdicional poderá ser mais uma vez convocada se o seu cumprimento sofrer percalço, seja pela inércia do obrigado, seja por suạ resistência, seja pelo atendimento insatisfatório da prestação. Nasce, aí, a pretensão à execução forçada.

$O$ certo é que, para alcançar o momento 3, o da execução, pressupõe-se superado o momento 2: executa-se a norma concreta já definida em seus contornos. Isso vale tanto para a execução espontânea, quanto para a forçada. Há, porém, um importante pressuposto a distinguir uma da outra. Aquela, a execução espontânea, pode ocor- 
rer independentemente de qualquer formalidade no processo de identificação da norma; mas esta, a execução forçada, pressupõe que a norma concreta esteja formalmente identificada, de modo que o seu conteúdo possa ser demonstrado ao juiz da execução com razoável grau de certeza.

Surge, assim, o título executivo, que pode ser conceituado como a representação documental de uma norma jurídica individualizada, contendo obrigação líquida, certa e exigível, de entregar coisa, ou de fazer, ou de não fazer, ou de pagar quantia em dinheiro, entre sujeitos determinados, e que tem a eficácia específica de viabilizar a tutela jurisdicional executiva. É o legislador que estabelece as características formais da representação documental que deve assumir a norma individualizada para ensejar a outorga da tutela jurisdicional executiva. Ela poderá ser produzida integralmente mediante controle jurisdicional, e constituirá título executivo judicial; poderá ser originada sem nenhuma participação do Estado-juiz e será título extrajudicial; e, finalmente, a identificação da norma concreta poderá estar representada em parte por documentação extrajudicial e em parte judicial, e o título executivo será misto. ${ }^{4}$ Uma coisa, porém, é certa: quando uma norma jurídica concreta estiver integralmente identificada mediante atividade jurisdicional, o legislador já não poderá negar-lhe a eficácia executiva, pois isso constituiria atentado ao direito constitucional de ação, que compreende, como é sabido, também o direito ao exercício da pretensão de executar.

\section{SENTENÇAS CONDENATÓRIAS}

A tese segundo a qual apenas sentença condenatória é título executivo, verdadeiro dogma para a maioria da doutrina, é de difícil demonstração. A dificuldade reside, desde logo, na identificação da natureza dessa espécie de sentença. Para Liebman, "a sentença condenatória tem duplo conteúdo e dupla função: em primeiro lugar, declara o direito existente - e nisto ela não difere de todas as outras sentenças (função declaratória); e, em segundo lugar faz vigorar para o caso concreto as forças coativas latentes na ordem jurídica, mediante aplicação da sanção adequada ao caso examinado - e nisto reside a sua função específica, que a diferencia das outras sentenças." ${ }^{.5}$ Fazer vigorar a força coativa da sanção não constitui, propriamente, função da sentença condenatória, mas sim da ação executiva que a ela posteriormente segue. Pois bem, conforme observou Barbosa Moreira, "se não é de efetivar a sanção que se trata na sentença condenatória, então só uma coisa é concebível que se trate: de declarar a sanção a que se sujeita o vencido." ${ }^{6}$ É assim, ali-

4 Sobre título executivo misto, ZAVASCKI, Teori Albino. Título Executivo e Liquidação. São Paulo: Revista dos Tribunais, 1999. p. 64, onde também discorremos sobre o temário abordado no presente estudo.

5 LIEBMAN, Enrico Tullio. Processo de Execução. 3. ed. São Paulo: Saraiva, 1968. p. 16. 6 MOREIRA. Reflexões... p. 76. 
ás, que Carnelutti via a sentença condenatória: uma sentença de dupla declaração, a declaração de certeza do que foi e do que devia ser. ${ }^{7}$ Calamandrei, a sua vez, descreveu a sentença condenatória como a decisão "mediante la cual la autoridad judicial individualizará el concreto precepto jurídico nacido de la norma, establecerá la certeza acerca de cuál ha sido y cuál habría debido ser el comportamento del obligado y determinará, como consecuencia, los médios prácticos aptos para restablecer en concreto la observância del derecho violado." "

Todavia, conforme anotou o próprio Calamandrei, "nem todas as sentenças condenatórias pressupõem ato ilícito", assim como "nem todas as sentenças que certificam o ilícito são sentenças condenatórias." "Ratificando tal objeção, Barbosa Moreira cita como exemplo de sentença condenatória, mas "sem correspondência com atos ou comportamentos antijurídicos", a da "condenação do litigante vencido ao pagamento das custas processuais e dos honorários de advogado do vencedor, nos sistemas que prevêem como corolário do mero fato do sucumbimento." "it Cita, outrossim, as "hipóteses em que se permite ao juiz proferir, antes de vencida a obrigação, sentença idônea para constituir, se o réu não a cumprir sponte sua, título executivo para o autor vitorioso." "Poder-se-ia referir outros exemplos, como o das sentenças homologatórias de conciliação ou de transação, que, em nosso sistema, constituem título executivo, inclusive, se for o caso, em favor do réu, e que têm por conteúdo, às vezes, direitos que sequer foram objeto da demanda. Em tais situações certamente não há juízo sobre ilícito ou sua sanção. Não é a aplicação da sanção a um ilícito, portanto, a nota característica da executividade dessa espécie de sentença.

Calamandrei busca superar tais objeções sustentando que a característica da sentença condenatória não está na aplicação ou na declaração da sanção. "Somente há condenação", diz ele, "quando, por força da sentença, o vínculo obrigacional é substituído por um vínculo de sujeição. A transformação da obrigação em sujeição, esta me parece ser verdadeiramente a função específica da condenação". E acrescenta: "pode-se dizer que a função da sentença de condenação é a de constituir aquele estado de sujeição, por força do qual o condenado é posto à mercê dos órgãos executivos e submetido a suportar passivamente a execução forçada como um mal inevitável."12

7 CARNELUTTI, Francesco. Derecho y proceso. Tradução Santiago Sentis Melendo. Buenos Aires: Europa-America, 1971. v. 1. p. 66.

8 CALAMANDREI, Piero. Instituciones de derecho procesal civil. Tradução Santiago Sentis Melendo. Buenos Aires: Europa-America, 1986. v. 1. p. 142.

9 CALAMANDREI, Piero. La Condana. In: Opere Giurideche. Nápoli: Morano 1972. v.5. p. 486.

10 MOREIRA. Reflexões... p. 74.

11 Ibidem, p. 75.

12 CALAMANDREI, op. cit. p. 492. 
Ocorre que o estado de sujeição a que se refere Calamandrei é próprio de qualquer título executivo, inclusive dos extrajudiciais, e não apenas da sentença condenatória. Ele não é, portanto, "constituído" pelo ato sentencial. É, antes, consequiência natural da norma jurídica consubstanciada no título executivo, mais especificamente do enunciado da perinorma, que eștabelece a sanção jurídica para a hipótese de descumprimento. Aliás, esta mesma objeção pode ser colocada à doutrina de Liebman, quando sustenta que a sanção à violação do direito é constituída pela sentença condenatória, e daí a razão de ser ela, no seu entender, pré-requisito indispensável à execução forçada. Também a sanção jurídica decorre da norma, e não da sentença. Esta, no máximo, a identifica e declara.

Com efeito, a sanção jurídica, assim considerada como a reação do direito à inobservância ou à violação das suas normas, não só está prevista no preceito normativo, como também constitui um dos seus elementos essenciais, o da perinorma (ou norma secundária), cujo destinatário é o órgão estatal encarregado de prestar jurisdição. "O que se chama de sanção", diz Bobbio, "outra coisa não é senão o comportamento que o juiz deve ter em uma determinada circunstância."'3 Atribuir ao lesado a faculdade de exigir a prestação jurisdici- onal é, portanto, qualidade inerente à própria norma jurídica. É justamente essa atributividade ou, como preferem alguns, esse autorizamento, ${ }^{14}$ a mais marcante diferença entre a norma jurídica e as outras normas de conduta: "a essência específica da norma jurídica é o autorizamento, porque o que compete a ela é autorizar ou não o uso dessa faculdade de reação do lesado. A norma jurídica autoriza que o lesado pela violação exija o seu cumprimento ou a reparação pelo mal causado." "I5 "A norma jurídica permite que o lesado pela violação dela exija o cumprimento dela", escreveu Goffredo Telles Júnior, acrescentando: "em virtude do autorizamento, o lesado pode, com fundamento jurídico, completar sua interação com quem o prejudicou. Após a ação violadora da norma jurídica, a própria norma violada autoriza e permite a reação competente." ${ }^{16}$ Esse é, aliás, o elemento distintivo por excelência entre a norma jurídica e as demais normas de conduta: a aptidão para atribuir ao lesado a faculdade de exigir o seu cumprimento forçado. Segundo a lição clássica de Luis Recasens Siches,

en el Derecho, cabalmente la posibilidad predeterminada de esa ejecución forzada, de la imposición inexorable de lo determinado en el precepto jurídico, incluso por medio de poder fisico, constituye un ingrediente esencial de éste. La

13 BOBBIO, Norberto. Teoria general de derecho. Tradução Jorge Guerrero R.. 2ed. Santa Fe de Bogota, Colombia: Temis, 1992. p. 125.

14 TELLES JÚNIOR, Goffredo. Direito Quântico. São Paulo: Max Limound. p. 263.

15 DINIZ, Maria Helena Diniz. Compêndio de Introdução à Ciência do Direito. 8. ed. São Paulo: Saraiva, 1995. p. 341.

16 TELLES JÚNIOR. Direito Quântico. p. 263. 
sanción jurídica, como ejecución forzada de la conducta mandada en el precepto [...], o como ejecución forzada de una conduta sucedánea de reparación o compensación, o como retribución de una infracción consumada ya irremediable - pena - constituye un elemento esencial de la norma jurídica. ${ }^{17}$

É equívoco, portanto, afirmar que a sentença condenatória, ou outra sentença qualquer, é constitutiva da sanção ou do estado de sujeição aos atos de execução forçada. Não é esta, conseqüentemente, a justificação para a força executiva dessa espécie de sentença. Sua executividade decorre, isto sim, da circunstância de se tratar de sentença que traz identificação completa de uma norma jurídica individualizada, que, por sua vez, tem em si, conforme se viu, a força de autorizar a pretensão à tutela jurisdicional. Se há "identificação completa" da norma individualizada é porque a fase cognitiva está integralmente atendida, de modo que a tutela jurisdicional autorizada para a situação é a executiva.

Ocorre que tais virtudes e características não são exclusivas da sentença condenatória, podendo ser encontradas em outros provimentos jurisdicionais, inclusive em certas sentenças declaratórias. Veja-se.

\section{SENTENÇAS DECLARATÓRIAS}

A ação puramente declaratória, e, portanto, a sentença que nela vier a ser proferida, tem por objeto, segundo o artigo $4^{\circ}$ do CPC, a declaração "da existência ou inexistência de relação jurídica" ou "da autenticidade ou falsidade de documento". Segundo os padrões tradicionais, não compõe seu objeto o juízo a respeito da violação da norma individualizada ou da sanção correspondente. A declaração de certeza, nestas ações, refere-se, como ensinava Calamandrei, ao preceito primário ("no transgredido todavia, pero incierto") e não ao mandado sancionatório. ${ }^{18}$

Nesse pressuposto, identificada a relação entre o objeto da ação puramente declaratória e a norma primária (enunciado endonormativo), conclui-se que nela não se faz juízo sobre a sanção (enunciado da perinorma), do que somente se poderia cogitar caso já tivesse havido violação. Por isso mesmo, aliás, a doutrina clássica a respeito das lides que fazem surgir interesse de mera declaração assinala o caráter preventi$v o$ da correspondente tutela jurisdicional. Não são lides de dano, mas de probabilidade de dano, dizia Carnelutti, ${ }^{19}$ e têm origem, não no descumprimento da obrigação, mas sim na dúvida a respeito da existência da relação jurídica, ou do seu modo de ser ou, quem sabe, do conteúdo da prestação ou da sanção que, no futuro, poderá ser exigida. Evidencia-se, assim, que, em regra, na sentença puramente declaratória há enunciados de certeza sobre um ou mais de um dos elementos da norma jurídica

17 RECASENS SICHES, Luis. Estudios de filosofia del derecho. Barcelona: Bosch 1936. p. 128. No mesmo sentido: DINIZ. Compêndio... p. 341.

18 CALAMANDREI. Instituciones... p. 152 e 168.

19 CARNELUTTI. Derecho y Proceso. p. 67. 
concreta, mas não sobre o seu todo (endonorma e perinorma), nem, especialmente, sobre a existência de uma prestação exigivel.

Assim entendida tal espécie de sentença, faz sentido afirmar, na linha do pensamento clássico, que elas não constituem títulos executivos, e se acrescenta - também sob influência desses mesmos padrões -, que apenas as sentenças condenatórias, que trazem identificação completa da norma individualizada, podem servir de base à execução. O Código de Processo Civil de 1939 refletia justamente essa doutrina, quando dispunha, no seu artigo 290, que "na ação declaratória, a sentença que passar em julgado valerá como preceito, mas a execução do que houver sido declarado somente poderá promover-se em virtude de sentença condenatória".

Ocorre que o Código de 1973, no parágrafo único do artigo $4^{\circ}$, trouxe dispositivo inovador: "é admissível a ação declaratória ainda que tenha ocorrido a violação do direito". Ao assim estabelecer, dá ensejo a que a sentença, agora, possa fazer juízo, não apenas sobre o preceito da endonorma (mandato primário não transgredido), mas também sobre o da perinorma (mandato sancionatório), permitindo, nesse último caso, juízo de definição inclusive a respeito da exigibilidade da prestação devida. Sentença de tal conteúdo representa, sem dúvida, um comprometimento do padrão clássico de tutela puramente declaratória (como tutela tipicamente preventiva), circunstância que não pode ser desconsiderada pelo intérprete.

Ora, se tal sentença traz definição de certeza a respeito, não apenas da exis- tência da relação jurídica, mas também da exigibilidade da prestação devida, não há como negar-lhe, categoricamente, eficácia executiva. Conforme assinalado anteriormente, ao legislador ordinário não é dado negar executividade a norma jurídica concreta, certificada por sentença, se nela estiverem presentes todos os elementos identificadores da obrigação (sujeitos, prestação, liquidez, exigibilidade), pois isso representaria atentado ao direito constitucional à tutela executiva, que é inerente e complemento necessário do direito de ação. Tutela jurisdicional que se limitasse à cognição, sem as medidas complementares necessárias para ajustar os fatos ao direito declarado na sentença, seria tutela incompleta. E, se a norma jurídica individualizada está definida, de modo completo, por sentença, não há razão alguma, lógica ou jurídica, para submetê-la, antes da execução, a um segundo juízo de certificação, até porque a nova sentença não poderia chegar a resultado diferente do da anterior, sob pena de comprometimento da garantia da coisa julgada, assegurada constitucionalmente. Instaurar a cognição sem oferecer às partes e principalmente ao juiz outra alternativa de resultado que não um já prefixado, representaria atividade meramente burocrática e desnecessária, que poderia receber qualquer outro qualificativo, menos o de jurisdicional. Portanto, repetimos: não há como negar executividade à sentença que contenha definição completa de norma jurídica individualizada, com as características acima assinaladas. Talvez tenha sido esta a razão pela qual o legislador de 1973, que in- 
cluiu o parágrafo único do artigo 4" do $\mathrm{CPC}$, não tenha reproduzido no novo Código a norma do art. 290 do CPC de 1939.

Interpretação sistemática do Código, especialmente depois das reformas que lhe foram impostas a partir de 1994, permite que se vá mais longe. Imaginese sentença que, em ação declaratória, defina, com força de coisa julgada, que a entrega de certa quantia de Pedro para Paulo foi a título de mútuo, e não de doação, e que o prazo para devolvê-la deve ocorrer (ou já ocorreu) em determinada data; ou que a ocupação do imóvel de Joana por Maria não é a título de comodato, mas de locação, e que o valor mensal do aluguel é de $\mathrm{R} \$ 300,00$, pagáveis no dia 30 de cada mês. Há, em tal sentença, como se percebe, definição de norma jurídica individualizada, contendo obrigação da pagar quantia certa. Se a definição dessa mesma norma estivesse representada em documento particular assinado pelas partes e por duas testemunhas, ela constituiria título executivo, nos termos do inciso II, do art. 585 do CPC. Igualmente, se a definição decorresse de documento firmado perante tabelião. Também teria força executiva se tivesse sido definida por autocomposição (transação) referendada pelo Ministério Público, ou pela Defensoria Pública ou, ain$\mathrm{da}$, pelos advogados dos transatores. Ora, nos exemplos dados, a norma individualizada e a relação jurídica correspondente têm grau de certeza muito mais elevado: elas foram definidas em processo de que participaram não apenas as partes, mas também os seus advogados, e, sobretudo, o próprio Esta- do-juiz, dando ao ato certeza oficial. Nessas circunstâncias, negar força de título executivo a esta espécie de sentença seria atentar contra o sistema processual, sua lógica e os valores nele consagrados.

Não parece procedente, portanto, a afirmação de que as sentenças declaratórias jamais podem servir de base à execução forçada. Isso fica também evidenciado do exame, que a seguir se fará, da denominada "condenação para o futuro".

\section{OBRIGAÇÕES CONDICIONAIS E "CONDENAÇÃO PARA O FUTURO"}

Segundo dispõe o artigo 572 do CPC, "quando o juiz decidir relação jurídica sujeita a condição ou termo, o credor não poderá executar a sentença sem provar que realizou a condição ou que ocorreu o termo". Decorre desse preceito que: (a) é possível "decidir relação jurídica sujeita a termo ou condição" mesmo antes da ocorrência deles; e que (b) a decisão assim tomada é título executivo, quando acompanhada da prova de "que se realizou a condição ou que ocorreu o termo". Os que sustentam que apenas a sentença condenatória é apta a desencadear o processo de execução encontram dificuldades em justificar a executividade do provimento a que se refere o citado artigo, especialmente quando se refere a relação jurídica subordinada a condição suspensiva.

Realmente, em se tratando de ato ou negócio jurídico subordinado a condição suspensiva, enquanto não se realizar a condição não há direito subjeti- 
vo, já que não ocorreu eficácia alguma ("não se terá adquirido o direito, a que ela visa", diz o Código Civil, art. 118). ${ }^{20}$ Não há direito subjetivo e nem é certo que ele vá nascer. Inimaginável supor que a sentença que decide relação jurídica sujeita a condição suspensiva possa conter imposição de sanção: não houve violação nem é certo que irá haver, até porque a obrigação nem mesmo existe e sequer é possível saber se ela algum dia existirá. A sentença que assim dispusesse seria condicional e, portanto, nula. Ora, desconsiderada a pretensão do autor em haver a aplicação da sanção, o interesse de agir - e, portanto, a correspondente sentença - só pode dizer respeito, nessas ações, à necessidade de eliminar eventuais incertezas sobre a relação jurídica, ou seja, a sentença de procedência só pode ter natureza declaratória.

No que respeita à relação jurídica sujeita a termo (inicial), o problema não é muito diferente. É sabido que, nessa espécie de relação, o direito subjetivo existe mesmo antes do advento do termo, pois, ao contrário do que se passa com a condição suspensiva, ele nasce com a prática do ato ou com a celebra- ção do negócio jurídico. Não é menos certo, todavia, que, enquanto pendente o termo, não há inadimplemento da obrigação e a prestação é, portanto, inexigível. Em suma: não ocorreu violação do direito, nem há como saber, nesse momento, se ela efetivamente ocorrerá, já que não se pode descartar a hipótese de que, na ocorrência do termo, haja execução espontânea da obrigação pelo devedor. Não será cabível, portanto, nas circunstâncias, pleitear judicialmente a imposição de sanção. Sendo assim, e utilizando linguagem Carneluttiana, é de se supor que as lides eventualmente exsurgentes antes da ocorrência do termo não serão lides de dano, mas lides de perigo, ou seja, de "probabilidade de dano". ${ }^{21}$ Só podem ser lides que surgem pela contestação da existência da relação jurídica, ou do seu modo de ser, ou, quem sabe, do conteúdo da sanção que poderá vir a ser exigida em caso de futuro - mas ainda incerto - inadimplemento da prestação. Conseqüentemente, o interesse de agir estará limitado a obter, por sentença, um acertamento preventivo sobre a existência ou o conteúdo da relação jurídica, ${ }^{22}$ ou, como diria Calamandrei, "a elimi-

20 PEREIRA, Caio Mário da Silva. Instituições Direito Civil. Rio de janeiro: Forense. v.2. p. 82; DINIZ, Maria Helena Curso de Direito Civil Brasileiro. 10. ed. São Paulo: Saraiva, 1996. v.2. p. 132.

\section{CARNELUTTI. Derecho y Proceso. v. 1. p. 67.}

22 São raros os precedentes jurisprudenciais sobre sentença que julga relação jurídica sujeita a condição ou a termo. Especificamente sobre relação jurídica a termo, registram-se os casos de demandas promovidas contra administradoras de consórcio, que, com base em cláusula contratual, entendiam indevida a incidência de correção monetária sobre o valor das prestações a serem restituídas aos consorciados desistentes. A jurisprudência que se firmou no STJ foi no sentido de que, embora a restituição fosse devida tão somente depois de trinta dias do encerramento do plano (obrigação a termo, portanto), já detinha o consorciado, antes desse prazo, interesse de agir, considerada a manifesta e antecipada resistência da administradora em reconhecer o direito à referida 
nação preventiva da falta jurídica de certeza." ${ }^{23}$ Essa "função exclusivamente preventiva" é típica da sentença declaratória. Também aqui a sentença que, desde logo, impusesse sanção (condenatória) seria condicional e, portanto, nula (CPC, art. 460, § único), porque dependeria de prova futura da ocorrência do ilícito, ainda não acontecido.

É artificiosa, sob esse aspecto, a construção doutrinária em torno da denominada condenação para o futuro, formulada para manter o dogma de que somente a sentença condenatória é título executivo. "La denominada condena en futuro", escreveu Carnelutti,

no es otra cosa, en verdad, que disfrazar una decisión de declaración de mera certeza; ciertamente, si el incumplimiento no se ha verificado todavia, no puede haver declaración de responsabilidad y, con ella, sustancia de condena; la condena, en cuanto el obligado no cumpla en el futuro una obligación todavia no exigible en el ato de la declaración de certeza, no ofrece al juez certeza alguna sobre el incumplimiento $\mathrm{y}$, por tanto, se reduce a una mera declaración de certeza de la obligación, y no hay entre la declaración y la condena in futuro ninguna diferencia apta para explicar por qué en un caso, y no en el otro, la decisión deba ser susceptible de ejecución forzada. ${ }^{24}$

O título executivo, no caso do artigo 572 do CPC, não é, portanto, uma sentença condenatória. Ele, na verdade, têm uma composição mista, sendo formado (a) da sentença que "decidir a relação sujeita a condição", que tem natureza declaratória, só podendo dizer respeito à existência ou ao conteúdo do ato ou do negócio jurídico, e não da existência do direito ou da obrigação em si mesmos; (b) de documento comprobatório da realização da condição e, portanto, da certeza quanto à existência da obrigação; e (c) de documento comprobatório da ciência do fato pelo devedor, requisito configurador da exigibilidade.

\section{OUTROS PROVIMENTOS JURISDICIONAIS NÃO CONDENATÓRIOS QUE CONSTITUEM TÍTULO EXECUTIVO}

Há outros provimentos jurisdicionais que, embora com força executiva, não possuem as características de sentença de condenação, tal como definida na doutri-

correção. Sobre a natureza da pretensão que, nessas circunstâncias poderia ser judicialmente deduzida, não houve, contudo, harmonia de entendimento. Há precedentes no sentido de que se trata de "sentença condenatória a termo" (Resp 53.193-4, 3 a Turma, Min. Eduardo Ribeiro. DJ de 31.10.94), mas, em nosso entender, mais precisos são os julgados segundo os quais o consorciado pode é promover "ação para ver declarado seu direito à atualização de seu crédito" (Resp 56.316, Min. Ruy Rosado de Aguiar, DJ de 07.08.95). Aliás, o Tribunal de Justiça do Rio Grande do Sul, onde essas questões tiveram origem, admitindo a existência de interesse de agir do consorciado, deixou evidenciado, em acórdão de lavra do Des. Araken de Assis, a natureza preventiva (e, portanto, não condenatória) da tutela que, nestes casos, é conferida ao demandante (Apelação Cível

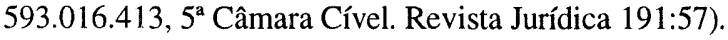

23 CALAMANDREI. Instituciones... p. 152.

24 CARNELUTTI. Derecho y Proceso. v.1. p. 355. 
na corrente. Assim, dão ensejo à execução forçada, por disposição do CPC, as seguintes sentenças: a) a de que trata o seu artigo 76 quando, ao julgar denunciação da lide, o juiz "declara, conforme o caso, o direito do evicto, ou a responsabilidade por perdas e danos"; b) a de que trata o $\S 2^{\circ}$ do artigo 899 , que julga ação consignatória em que o depósito oferecido pelo autor foi insuficiente, propiciando que o juiz determine o montante da insuficiência, ainda devido pelo autor (sentença que constituirá título executivo em favor do réu); c) a de que trata o artigo 918, quando, ao decidir ação de prestação de contas, o juiz declara, na sentença, o montante de saldo credor (que pode favorecer o autor ou o réu).

São também títulos que ensejam execução forçada as sentenças que têm como "efeito anexo" 25 o de tornar certa a obrigação de ressarcir danos. É o caso das sentenças que extinguem a execução provisória, das quais decorre, automaticamente, independentemente de condenação, a responsabilidade do exeqüente pelos prejuízos sofridos pelo executado, nos termos do artigo 588, I, do CPC. Da mesma forma, nas situações previstas no artigo 811 do CPC, nasce a executividade, independentemente de condenação, de provimentos jurisdicionais que produzem a ineficácia das medidas cautelares e das quais decorre, como conseqüência natural da ordem jurídica, a responsabilidade objetiva do requerente pelos prejuízos causados ao requerido. Outro exemplo significativo de sentença que dispensa condenação para ter força executiva é a que julga procedente a ação de resilição de contrato de promessa de compra e venda. Segundo a jurisprudência do STF, reafirmada pelo STJ, em casos tais, a sentença é título para a ação de execução visando a entrega da coisa, independentemente de ter havido pedido explícito ou condenação específica a respeito, pois a obrigação de restituir o bem é efeito necessário e natural da resolução do compromisso. ${ }^{26}$ Assemelham-se, tais hipóteses, à da sentença penal condenatória, da qual decorre, como efeito natural e necessário a obrigação de reparar os danos. Aliás, no âmbito do processo penal têm, igualmente, força executiva no juízo cível o acórdão do tribunal que, julgando procedente a ação de revisão criminal, reconhece ao interessado "o direito a uma justa indenização pelos prejuízos sofridos" em decorrência da indevida condenação (CPP, art. 630). Responderá pela indenização, independentemente de condenação específica, a União ou o Estado membro cuja Justiça tiver proferido a sentença revisada, cabendo ao juízo cível promover a liquidação $\left(\S 1^{\circ}\right)$ e a execução.

\section{CONCLUSÕES}

Pode-se afirmar, em conclusão, que: a) o título executivo é a representação

25 SILVA, Ovídio A. Baptista da. Sentença e Coisa Julgada. 2. ed. Porto Alegre: Fabris, 1988. p. 113.

26 STF, RE 99.339, $1^{\text {a }}$ Turma, Min. Sydney Sanches, RTJ 114:693; STJ, Resp 18.000, $4^{\mathrm{a}}$ Turma, Min. Sálvio de Figueiredo, DJ de 07.06.93. 
documental de uma norma jurídica individualizada, contendo obrigação líquida, certa e exigível, de entregar coisa, ou de fazer, ou de não fazer, ou de pagar quantia em dinheiro, entre sujeitos determinados; b) a sentença civil condenatória é título executivo porque contém definição completa de norma jurídica individualizada com aquele conteúdo; c) não se pode afirmar, contudo, que apenas essa sentença tem eficácia executiva, já que o sistema processual confere executividade a outros provimentos jurisdicionais sem natureza condenatória; d) não procede a afirmação de que a sentença meramente declaratória jamais é título executivo; ela terá força executiva quando contiver certificação de todos os elementos de uma norma jurídica concreta, relativa a obrigação com as características acima referidas.

\section{REFERÊNCIAS}

BOBBIO, Norberto. Teoria general de derecho. Tradução Jorge Guerrero R.. 2 ed. Santa Fe de Bogota, Colombia: Temis, 1992.

CALAMANDREI, Piero. Instituciones de derecho procesal civil. Tradução Santiago Sentis Melendo. Buenos Aires: Europa-America, 1986. v. 1.
La Condana. In: Opere Giurideche. Nápoli: Morano 1972. v.5.

CARNELUTTI, Francesco. Derecho y proceso. Tradução Santiago Sentis Melendo. Buenos Aires: Europa-America, 1971. v. 1.

DINIZ, Maria Helena Diniz. Compêndio de Introdução à Ciência do Direito. 8. ed. São Paulo: Saraiva, 1995. Curso de Direito Civil Brasileiro. 10. ed. São Paulo: Saraiva, 1996. v.2

LIEBMAN, Enrico Tullio. Processo de Execução. 3. ed. São Paulo: Saraiva, 1968.

MOREIRA, José Carlos Barbosa. Reflexões Críticas sobre uma Teoria da Condenação Civil. In: TEMAS de Direito Processual Civil: $1^{a}$ Série. São Paulo: Saraiva, 1977.

PEREIRA, Caio Mário da Silva. Instituições Direito Civil. Rio de janeiro: Forense. v.2.

RECASENS SICHES, Luis. Estudios de filosofia del derecho. Barcelona: Bosch, 1936.

SILVA, Ovídio A. Baptista da. Sentença e Coisa Julgada. 2 ed. Porto Alegre: Fabris, 1988.

TELLES JÚNIOR, Goffredo. Direito Quântico. São Paulo: Max Limound.

ZAVASCKI, Teori Albino. Título Executivo e Liquidação. São Paulo: Revista dos Tribunais, 1999. 


\section{METROFOLE \\ Indústria Gráfica Lida. \\ Fone/Fax: (51) 3318-6355 \\ e-mail: mig@ $@$ mig.com.br wuw.mig.com.br}




\section{Faculdade de Direito UFRCS}

Av. João Pessoa, n. 80 - CBP 90.040-000 - Porto Alegre/RS - Brasil Tel: (51) $3316-3118 / 3316-3128 / 3316-3555 / 3316-3464$

\section{REPRESENTANTES}

ACRE

M.M. Paim Representaçóes e Comércio - livrariapaim@uol.com.br

AMAZONAS

Travessia Editora e Livraria Ltda.-livraria_valer@hotmail.com

BAHIAISERGIPE

LDMLivraria e Distribuidora Multicampi Ltda. - Idm@livrariamulticampi.com.br

DISTRITO FEDERAL.

J. Quinderé Distribuidora de Livros Ltda. - F: (61) $347-8461$

GOIAS

Araújoe Dias Ltda. - dama@ih.com.br

MATO GROSSO

Marchi Liviaria e Distribuidora Ltda.-fmarchi@terra.com.br

MINAS GERAIS

Alpha Distribuidora de Livros Ltda. - alphalivros@bol.com.br

PARANA

LivrariaMillenium Ltda._livraria@milleniumlivraria.com.br

PERNAMBUCO

Livraria e Distribuidora Recife Ltda.-livrecif@hotlink.com.br

RIO DE JANEIRO

Prefácio Distribuidora de Livros Ltda. - prefacio@terra.com.br

RIO GRANDE DO NORTE

Potylivros Distribuidora Ltda.-potylivros@digi.com.br

RIO GRANDE DO SUL

Multilivro Distribuidora e Livraria Ltda. - livro@via-rs.ne

SANTA CATARINA

Livraria Livros \& Livros Ltda.-livroselivrosestoque@terra.com.br

SÃO PAULO

Batatais Comercio e Represent. de Livros Ltda. - batatais@terra.com.br

EDUSP - Editora Universidade de São Paulo - isafonso@usp.br

Empório do Livro - emporiodolivro@uol.com.br

Tecmedd Distribuidora de Livros Ribeiräo Preto Ltda._tecmedd@tecmedd.com.br

TOCANTINS

S.G.Vieira - palmascultural@bol.com.br
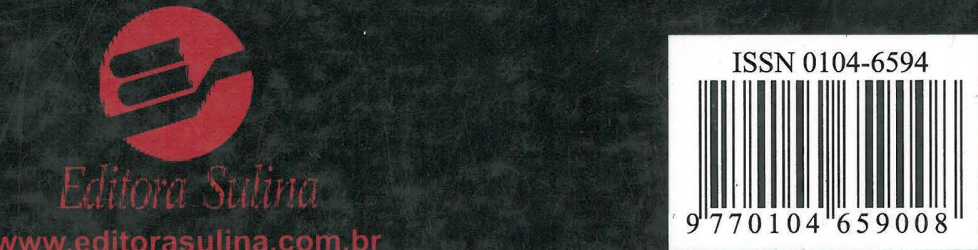